\title{
Challenges for a new decade of academic research: an editorial
}

\author{
Thomas W. Guenther ${ }^{1}$ (D)
}

(c) The Author(s) 2020

With the end of 2019, a decade with tremendous changes in the higher education sector ended and a new decade promising not minor changes has started. The societies we live in are challenged by macro-trends such as global warming, demographic change, urbanization, digitalization, resource scarcity or global environmental damages.

These macro-trends also have impact on research and teaching in the higher education sector. We face big threats, but also promising opportunities. Scholars have to react to demands for a third mission, to leave the ivory tower and to create benefits for firms, communities, economies and students alike. Digitalization is changing the working environments we study, but also our own working environments. Can we use massive open online courses (moocs) to improve the quality of teaching and to be more efficient? How can we use e-learning tools to better connect with students and to increase knowledge creating and learning effects? How can we apply more advanced IT tools such as machine learning or artificial intelligence to inspire our research methods? How will we exchange knowledge and discuss research in the future? Will we still have communication platforms such as conferences or workshops, or is an exchange of our ideas in video conferences or virtual classrooms more effective? Will we still write papers for academic journals or exchange our ideas and findings on social-media platforms? Many questions for which we see some developments, but for which we still do not have clear answers.

Changes in the academic environments, they maybe threats or opportunities, also affect the publication markets, and a journal such as the Journal of Management Control has to consider these developments for the upcoming decade. In the past, authors had to decide to either publish in a fully open access journal or to find funding for an open-access option within a traditional journal. Springer Nature recently announced a new "Publish-and-Read Agreement" with which corresponding authors from most German universities and research institutions can publish open access in JoMaC and most of their other subscription-based

Thomas W. Guenther

thomas.guenther@tu-dresden.de

1 Technische Universität Dresden, Dresden, Germany 
journals, with the fee being covered by public funding. Similar deals are already in place for other countries such as Sweden, Netherlands, UK, Norway, Finland, Poland, Hungary, Austria, or Katar. Thus, it looks like the best of both worlds, publishing open access and in established journals, can be combined.

Other questions are whether reviewers should be paid to further reduce reviewing cycles or whether authors should be motivated to revise their papers in much shorter periods of only a few weeks. So far, also for JoMaC, neither authors have to pay for their submissions, nor reviewers are paid for their valuable service to the academic community. Another issue is whether we can avoid publication bias by reviewing extended abstracts (only), but not the final results of empirical papers. Thus, there is movement in the publication market and we are well adviced not only to adjust our publication processes to the requirements of the markets, but also to co-design new avenues to knowledge creation.

Looking back on 2019, the Journal of Management Control has gained international recognition. In relation to 2018 , the number of submissions doubled, and in relation to 2013 we almost reached four times the volume of submissions. The average number of days between the date of the receipt of the manuscript and the first decision (submission to first decision) is 49 days which is pretty low. Editors do not intend to reduce this further to give reviewers, besides their other duties, enough time for a high-qualitative, supporting reviews. The average time between submission and acceptance in 2019 was relative low with 273 days. The Journal of Management Control gets more and more international. For example, in 2019 submissions, regarding country of origin of the corresponding author, came from 37 different countries around the world. The same holds for the origin of our reviewers. Full-text downloads of papers reached with more than 69,000 downloads an all-time high in 2019, almost doubling since 2016.

To reflect the growth and to support the further development of our journal, Frank Verbeeten, University of Amsterdam, and long-time editor of the Journal of Management Control, will join Thomas Guenther as a second managing editor starting January 1, 2020. We are grateful for his engagement and commitment and wish him all the best for his new responsibility.

Since 2012, we have honored our best reviewers every year. For the year 2018, the editors want to thank five scholars representing our valuable resource of reviewers for their excellent support given to authors to further develop their papers and for their great support of the Journal of Management Control.

Best reviewer award 2018:

Distinguished Reviewers 2018:
Berend van Kolk, IE Business School, Spain

David Bedford, University of Technology Sydney, Australia;

Martin Quinn, Quenn's University, Belfast, Northern Ireland, UK;

Lucia Bellora-Bienengräber, University of Hamburg, Germany;

Christian Nitzl, Bundeswehr University, Munich, Germany 
We also proceed in international rankings. In 2018, we were included for the first time in the Academic Journal Guide of the Chartered Association of Business Schools (CABS) in the UK, and in 2019 we were ranked as an A-journal in the Australian Business Deans Council (ABDC) Journal Quality List.

The editors of the Journal of Management Control also want to draw your attention to a forthcoming special issue in our journal. For further information please see the call for papers on our website.

\section{Special issue "Experiments, Replications and the Advancement of Management Accounting and Control Research"}

Guest editors: Alexander Brüggen, Maastricht University, The Netherlands; Victor Maas, University of Amsterdam, The Netherlands; Alexandra Van den Abbeele, KU Leuven, Belgium.

\section{Deadline: March 31, 2020}

This issue of the Journal of Management Control presents four papers of different topics and of different methodological approaches from the wide field of management accounting and control.

Marit Terese Balstad and Terje Berg explore which journals publish management accounting research and which sources are most cited in these journals. They use bibliometric methods based on citation data from Web of Science and Scopus and analyse 506,753 and 1,075,838 cited references from each respective database in the timespans 1945-2018 and 1960-2018. Based on this large data base diversity of publications is further analysed. They also discuss Google Scholar as an additional resource for bibliometic analysis.

Brian D. Knox uses an experimental approach to analyse whether a strategy map may help mitigate bias in middle managers' feedback reporting decisions. Middle managers usually have significant control over the access of upper management to lower-level employee feedback because they finally decide whether and how to forward that feedback when they receive it. The author shows that a strategy map can help de-bias some of the feedback middle managers forward to upper management.

Escalation of commitment, that is a decision-maker's tendency to continue with a failing project or activity due to sunk costs, is often very costly and signals a failure of managerial decision-making. Christine R. Ohlert and Barbara E. Weißenberger examine the effectiveness of different types of decision aids that aim to reduce this sunk cost effect. Using different experiments, they demonstrate that the sunk cost effect even occurs although new unequivocal information on the project's prospects suggests to change the course, making this bias a robust decision-making error. When exploring different decision aids, the authors found that aids that label sunk costs as such and warn about the sunk cost effect were not effective, whereas specific 
instructions that alert the decision-maker how to apply normative decision rules for incremental investment decisions effectively reduced decision-maker's escalation of commitment. As escalation of commitment is highly relevant for practice, consequences for management accounting practice are further discussed.

Existing management control literature has underlined the importance of examining and better understanding complementarity effects originating from the adoption and use of multiple management controls (i.e., as a management control systems). In configurations of management controls, a number of control forms work interdependently. These interdependencies may produce complementarity effects, which previous literature has not captured in full, as synergy effects from interdependencies in configurations are often treated implicitly or tested too reductionistic. Thomas Borup Kristensen and Henrik Nielsen develop novel test formulas to test performance effects from balancing control forms in management control systems addressing complementarity effects. The developed test formulas are illustrated using survey-data on whether multiple roles of management accountants can affect performance in a complementing manner from the background of the firm's strategy they support.

We hope that our readers may enjoy reading the articles in this issue and may derive new ideas for their own research, but we also hope that these pieces of research may inspire researchers to translate their findings to improve practice.

Dresden, January 2020

For the team of editors

Thomas W. Guenther

Frank Verbeeten

Managing editors

Acknowledgements Open Access funding provided by Projekt DEAL.

Open Access This article is licensed under a Creative Commons Attribution 4.0 International License, which permits use, sharing, adaptation, distribution and reproduction in any medium or format, as long as you give appropriate credit to the original author(s) and the source, provide a link to the Creative Commons licence, and indicate if changes were made. The images or other third party material in this article are included in the article's Creative Commons licence, unless indicated otherwise in a credit line to the material. If material is not included in the article's Creative Commons licence and your intended use is not permitted by statutory regulation or exceeds the permitted use, you will need to obtain permission directly from the copyright holder. To view a copy of this licence, visit http://creativecommons.org/licen ses/by/4.0/.

Publisher's Note Springer Nature remains neutral with regard to jurisdictional claims in published maps and institutional affiliations. 